\title{
Effect of Pre-Drying and Hydrocolloids Batter Coating during Heat and Moisture Transfer of Coated Fried Potato Chips
}

Sunday Samuel Sobowale* and Benjamin Oluwole Omotoso

Department of Food Technology, Moshood Abiola Polytechnic, Abeokuta, Ogun State, Nigeria

*Corresponding author: Sunday Samuel Sobowale, Department of Food Technology, Moshood Abiola Polytechnic, Abeokuta, Ogun State, Nigeria, Tel: +2348033791755; E-mail: sobowale.sam@gmail.com

Received date: May 18, 2018; Accepted date: May 25, 2018; Published date: May 31, 2018

Copyright: (C) 2018 Sobowale SS, et al. This is an open-access article distributed under the terms of the Creative Commons Attribution License, which permits unrestricted use, distribution, and reproduction in any medium, provided the original author and source are credited.

\begin{abstract}
Fat uptake is considered the major nutritional critical point of deep frying because of the obesity and negative effect of excess oil consumption on human health. Hence, this study investigated the effect of pre-drying and hydrocolloids batter coating during heat and moisture transfer of coated fried potato chips. The potato slices were pre-dried coated and deep fried at $180^{\circ} \mathrm{C}$ for $5 \mathrm{~min}$. Chemical composition, color profile; thermo-physical properties, dimensionless numbers associated with convective heat and mass transfer coefficient and sensory properties were evaluated. The result revealed that chemical composition and color profile were significantly $(p \leq 0.05)$ affected by pre-drying and hydrocolloids batter coating. The density, viscosity, thermal conductivity, specific heat capacity and thermal diffusivity ranged from $333.3-444.0 \mathrm{~kg} / \mathrm{m}^{3}, 0.5281-0.5377$ pas, $22.686-31.403 \mathrm{~W} / \mathrm{m}{ }^{\circ} \mathrm{C}, 198.686-258.383$ $\mathrm{KJ} / \mathrm{kgK}$ and $2.730 \times 10-4-3.826 \times 10^{-4} \mathrm{~m}^{2} / \mathrm{s}$, respectively. The estimated Grashof, Prandtl, Schmidt, Nusselt and Sherwood numbers ranged between 0.024-0.032, 4.14-4.71, $2.053 \times 10^{-5}$ and $2.739 \times 10^{-5}, 0.0167-0.0209,9.70 \times$ $10^{-8}$ and $1.02 \times 10^{-7}$, respectively. The heat and mass transfer coefficient values ranged from 25.26 to $42.98 \mathrm{~W} / \mathrm{m}^{2}$ ${ }^{\circ} \mathrm{C}$ and $3.80 \times 10^{-12}$ to $4.01 \times 10^{-12} \mathrm{~m} / \mathrm{s}$, respectively. Hydrocolloid type distinctly dictated considerable quality attributes and apparently potato chips pre-dried, coated with egg albumin and carboxyl methylcellulose were gum tragacanth demonstrates great reduction in the fat content of the chips which will in turn decline the tendency of obesity and equally reduce cholesterol level.
\end{abstract}

Keywords: Pre-drying; Frying; Sweet potato; Hydrocolloids; Heat and moisture transfer

\section{Introduction}

Globally, one of the most cultivated root and tuber crops in the tropic and subtropics includes sweet potato (Ipomea batatas L). Central America is documented as its base origin, but it is now grown and consumed as subsistence staples in many parts of Africa, Latin America, the Pacific Islands and Asia [1]. Economically, it is valued for short duration of cultivation and nutritionally gives account of annual source of dietary fiber, mineral, vitamin A and C, and offers more daily edible energy per hectare than most consumed cereals and cassava [2]. Health benefits from sweet potato consumption have been found to reduced blood cholesterol, digestion and equally contributing sizable amounts of daily vitamins to school age children (Figures 1-5)

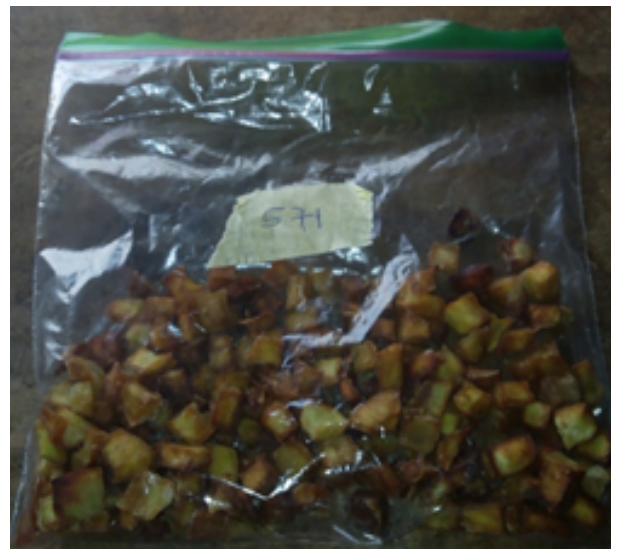

Figure 1: Fried potato chips. 
Citation: Sobowale SS, Omotoso BO (2018) Effect of Pre-Drying and Hydrocolloids Batter Coating during Heat and Moisture Transfer of Coated Fried Potato Chips. J Bioprocess Biotech 8: 328. doi:10.4172/2155-9821.1000328

Page 2 of 9

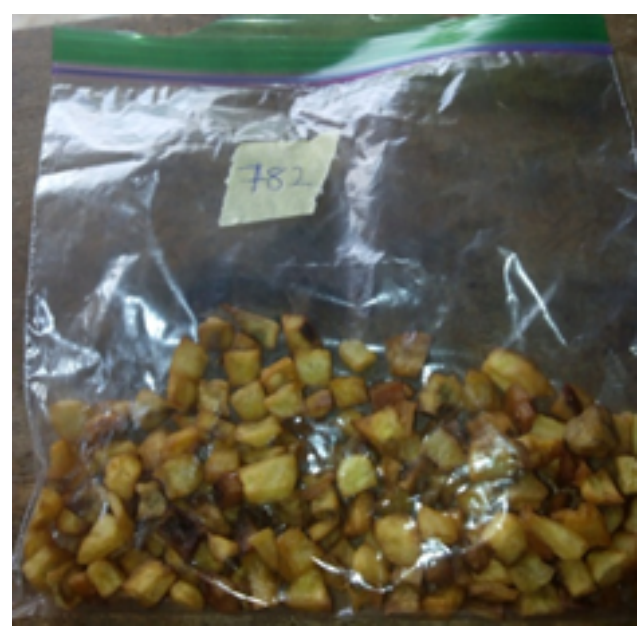

Figure 2: Pre-dried potato chips.

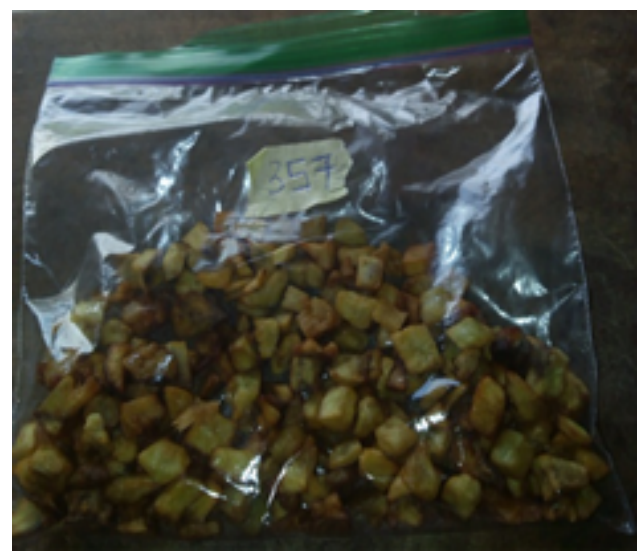

Figure 3: Pre-dried potato chips coated with egg albumin.

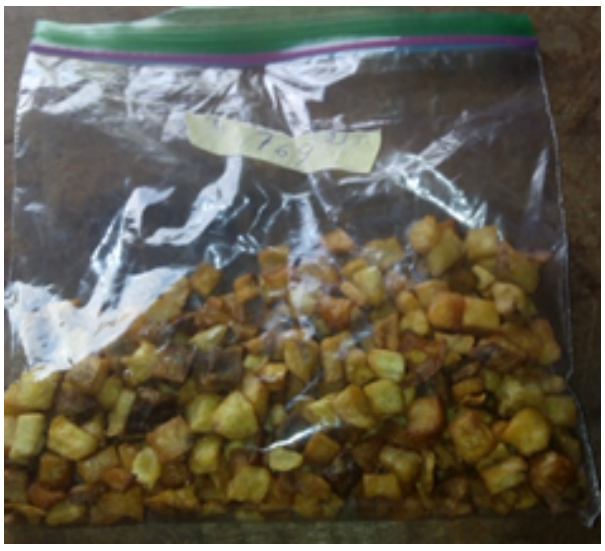

Figure 4: Pre-dried potato chips coated with egg albumin and Carboxyl Methyl Cellulose.

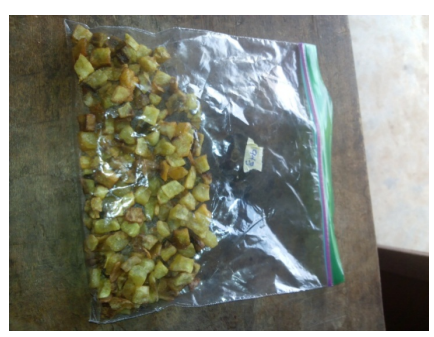

Figure 5: Pre-dried potato chips coated with egg albumin and gum tragacanth.

Deep fat frying involves immersion of food in hot edible oil at a temperature above the boiling point of water for duration of time, where moisture is migrated out and oil is absorbed in the fried food through phenomena of heat and mass transfer [3,5]. Consumption of sweet potato by mode of frying is native in Sub-Saharan Africa countries and serve as a quick-fill food in an environment where time consciousness permits people to eat on the go. Common practice of partial drying and coating surfaces of food products prior to deep-fat frying have beneficial effects by optimizing the moisture loss and oil uptake during frying [6,7] imparts desirable color and textural properties [8] and supplies added nutrients to the fried food $[9,10]$. However, coating materials tend to loss during frying due to swift movement of moisture from food being fried [11] and therefore accelerates the rate of degradation of the frying medium [12]. Nevertheless, addition of hydrocolloids to the coating will bring about reduced coating loss due to their inherent property of surface adherence and influence on coating viscosity [13] but it enhances water retention in fried foods [14].

Moreover, the effect of pre-drying and hydrocolloids batter coated fried product during heat and mass transfer is scarce and has not been reported in detail to explore the relationship between process variables and the quality characteristics of fried potato chips. This point has caught the attention of several researchers. In recent years, there has been strong encouragement to reduce oil content of fried food, prompting many researchers on the development of food product that have reduced fat and cholesterol level (use of egg white). Hence, the aim of this study is to investigate the effect of pre-drying and hydrocolloids batter coating during heat and moisture transfer of coated fried potato chips.

\section{Materials and Methods}

\section{Materials}

Fresh sweet potato (Ipomoea batatas) variety and poultry eggs were obtained from Kuto market $\left(10^{\circ} \mathrm{N}, 25^{\circ} \mathrm{E}\right)$ in Abeokuta, South West Nigeria for the research.

\section{Methodology}

Preparation of the sample: The sweet potato was prepared using the method [15]. The outer layer of sweet potato was peeled off using a sharp knife into 30 and $45 \mathrm{~mm}$ dimension. The samples were cut into sizes using cutter and slicer. Fresh poultry egg was washed with distilled water to remove extraneous materials and cracked to release the content. The egg white was obtained by careful separation from egg 
yolk [15]. The coating was formulated by mixing $0.5 \mathrm{~g}$ carboxy- methyl cellulose (CMC) or gum tragacanth (GT) and $200 \mathrm{ml}$ of egg white in a commercial blender at a proportion of $0.5 \mathrm{~g} / \mathrm{ml}$ until the mixture was uniform and free of lumps.

Pre-drying operation: The potato slices were spread on a single layer tray with space between slices for air movement and dried in convective hot air oven (NYC-101 oven, FCD-3000 serials, Medical and Scientific, England) at $75^{\circ} \mathrm{C}$ for $15 \mathrm{~min}$.

Coating and frying of potato slices: The potato slices were coated with egg albumin and carboxy-methylcellulose (CMC) or gum tragacanth (GT), fried in an electrical deep fryer (Master Chef Mcdf1023 Australia) at $180^{\circ} \mathrm{C}$ for $5 \mathrm{~min}$ for each set of treatment and control [15]. Excessive oil was drained off from the chips after removal from the fryer for about $50 \mathrm{sec}$.

Determination of coating pick up: The coating picks up was determined using the method [8] with the use of electronic weighing balance (Amput, Model number: 457, England). Amount of coating adhering to the substance was considered as coating pick up (CPU) and calculated as:

$$
\% \mathrm{CPU}=\mathrm{C}-\mathrm{Y} / \mathrm{Y} \times 100
$$

Where, $\mathrm{Y}$ is the weight of potato chips and $\mathrm{C}$ is the weight of potato chip after coating.

Determination of moisture loss and oil uptake: The moisture loss and oil uptake were determined according to the method of AOAC [16]. The moisture content of fresh potato chip was determined by gravimetric method in triplicates. Moisture content was calculated as weight loss after drying of sample in a forced convection oven at $105^{\circ} \mathrm{C}$ to constant weight.

Color measurement determination: The color measurement was obtained using [17] Adobe Photoshop 6.0 software and normalized to $\mathrm{L}^{*}, \mathrm{a}^{*}, \mathrm{~b}^{*}$ according to the following equations:

$$
\begin{aligned}
& \% \mathrm{CPL}^{*} \mathrm{o}=\mathrm{L} / 255 \times 100 \\
& \mathrm{a}^{*}=\mathrm{a}^{*} 240 / 255-120 \\
& \mathrm{bo}^{\star}=\mathrm{b}^{\star} 240 / 255-120
\end{aligned}
$$

Also, color difference was calculated as stated below:below:

$$
E^{*}=\left[\left(L^{*} \mathrm{O}-\mathrm{L}^{\star}\right) 2+\left(\mathrm{a} 0^{*}-\mathrm{a}^{\star}\right) 2+\left(\mathrm{b} 0^{*}-\mathrm{b}^{*}\right) 2\right] 1 / 2
$$

\section{Determination of proximate composition}

The proximate composition of fried potato chips was determined using the method of AOAC [18].

\section{Thermo-physical properties}

Determination of density: $5 \mathrm{gm}$ of sample was weighed and put into $100 \mathrm{ml}$ measuring cylinder containing $50 \mathrm{ml}$ water (as floatation liquid) the density was determined using simple floatation principle [19].

Determination of specific heat capacity (CP): The methods [20,21] were adapted with the use of two lagged copper calorimeters.

$$
\mathrm{Cp}=1 / \mathrm{Mp}[\mathrm{MwCwGw} / \mathrm{Gp}-\mathrm{McCc}] / 60
$$

where, $M_{p}, M_{w}$ and $M_{c}$ are the mass of sample, water and calorimeter, respectively; $\mathrm{C}_{\mathrm{w}}$ and $\mathrm{C}_{\mathrm{c}}$ are the specific heat capacity of water and calorimeter, respectively; $G_{w}$ and $G_{p}$ are the slope of cooling curve for water and sample, respectively.

Determination of thermal diffusivity (a): This method [22] was adapted with the use of probe connected by K-thermocouple wires to an Alda AVD 890C+ digital Multimeter. At Fourier 0.1, the solutions to the heat transfer equation for an infinite geometry was determined as follows:

$$
\operatorname{Ln}[\mathrm{Ts}-\mathrm{T} /(\mathrm{Ts}-\mathrm{Ti})]=\text { Constant }-(5.783 \alpha) \mathrm{t} / \mathrm{r} 2
$$

where, Ts is the medium temperature $\left({ }^{\circ} \mathrm{C}\right)$; $\mathrm{Ti}$ is the initial temperature of the sample $\left({ }^{\circ} \mathrm{C}\right), \mathrm{T}$ is the temperature of the sample at time, $\mathrm{t}\left({ }^{\circ} \mathrm{C}\right), \mathrm{r}$ is the radius or half the thickness of the sample $[23,24]$. The thermal diffusivity can then be calculated from the slope of a plot of the natural logarithm of the unaccomplished temperature $\mathrm{V}_{\mathrm{s}}$ time.

Determination of thermal conductivity (Ks): The thermal conductivity was estimated from the corresponding thermal diffusivity value specific heat $(\mathrm{Cp})$ and density $(\rho)[22,23,25]$. The thermal conductivity was then calculated using the expression:

$$
\alpha=\mathrm{Ks} / \rho \mathrm{Cp} \quad \rightarrow \quad \mathrm{Ks}=\alpha \dot{\rho} \mathrm{Cp}
$$

Determination of mass/moisture diffusivity: Experimental result was interpreted using fick's diffusion equation. The solution of this equation development by Crank [26] is applicable for food material with spherical shape by assuming uniform initial moisture distribution. Initial moisture content of the sample was gravimetrically measured by the method of AOAC [27]. A diffusion model based on fick's law of diffusion was used to describe the moisture diffusivity on three dimensional mass transfers on a steady and unsteady state [28].

$$
\frac{\gamma_{m}}{\gamma_{t}}=D_{m}\left(\frac{\gamma^{2} m}{\gamma^{2} c}+\frac{1}{r c \gamma m / \gamma r^{2} c}+\frac{\gamma_{m}}{\gamma_{2}{ }^{2}}\right)
$$

where: Dm=Effective moisture diffusivity/mass diffusivity $\left(\mathrm{m}^{2} / \mathrm{s}\right)$, $\mathrm{M}=$ moisture content $(\mathrm{kg} / \mathrm{kg} \mathrm{db}), \mathrm{Vc}=$ cylindrical radium $(\mathrm{m}), \mathrm{Vt}=$ time (s), $\mathrm{Z}=\mathrm{z}$-direction coordinate.

Convective heat and mass transfer coefficients: The convective heat and mass transfer coefficients were estimated from the corresponding thermo-physical data and estimated dimension less numbers $[29,30]$.

\section{Heat transfer coefficient (hc)}

$$
\begin{array}{lc}
\mathrm{N}_{\mathrm{Nu}}=h_{\mathrm{c}} \mathrm{d} / \mathrm{k}_{\mathrm{s}}=\mathrm{f}\left(\mathrm{N}_{\mathrm{Re}}\right)^{\mathrm{m}} \cdot\left(\mathrm{N}_{\mathrm{Pr}}\right)^{\mathrm{n}} & \text { (For forced convection) } \\
\mathrm{N}_{\mathrm{Nu}}=\mathrm{h}_{\mathrm{c}} \mathrm{d} / \mathrm{k}_{\mathrm{s}}=\alpha\left[\left(\mathrm{N}_{\mathrm{Gr}}\right) \cdot\left(\mathrm{N}_{\mathrm{Pr}}\right)\right]^{\mathrm{C}} & \text { (For natural convection) } \\
\mathrm{h}_{\mathrm{c}}=\mathrm{N}_{\mathrm{NU}} \mathrm{K}_{\mathrm{s}} / \mathrm{d} & \text { (12) }
\end{array}
$$

\section{Mass transfer coefficient $(\mathbf{h m})$}

$$
\begin{aligned}
& \mathrm{N}_{\mathrm{Sh}}=\mathrm{h}_{\mathrm{m}} \mathrm{d} / \mathrm{D}_{\mathrm{m}}=\mathrm{f}(\mathrm{NRe}) \mathrm{m} \cdot\left(\mathrm{N}_{\mathrm{Sc}}\right)^{\mathrm{n}} \quad \text { (For forced convection) } \\
& \mathrm{N}_{\mathrm{Sh}}=\mathrm{h}_{\mathrm{m}} \mathrm{d} / \mathrm{D}_{\mathrm{m}}=\alpha\left[\left(\mathrm{N}_{\mathrm{Gr}}\right) \cdot\left(\mathrm{N}_{\mathrm{Sc}}\right)\right]^{\mathrm{C}} \\
& \mathrm{h}_{\mathrm{m}}=\mathrm{N}_{\mathrm{sh}} \cdot \mathrm{D}_{\mathrm{m}} / \mathrm{d}
\end{aligned}
$$

The values of $\mathrm{f}, \mathrm{m}$, and $\mathrm{n}$ are the function of $\left(\mathrm{N}_{\mathrm{Re}} \cdot \mathrm{N}_{\mathrm{Pr}}\right)$ and $\left(\mathrm{N}_{\mathrm{Re}} \cdot \mathrm{N}_{\mathrm{Sc}}\right)$, while $\alpha$ and $\mathrm{c}$ is the function of $\left(\mathrm{N}_{\mathrm{Gr}} \cdot \mathrm{N}_{\mathrm{Pr}}\right)$ and $\left(\mathrm{N}_{\mathrm{Gr}} \cdot \mathrm{N}_{\mathrm{Sc}}\right)$ dimensionless parameters [31].

Where,

$\mathrm{N}_{\mathrm{Nu}}$ (Nusselt number)=hcd/ks, $\mathrm{N}_{\mathrm{Re}}$ (Reynolds number) $=\rho d v / \mu, \mathrm{N}_{\operatorname{Pr}}$ (Prandtl number) $=C_{p} \mu / k, N_{G r}$ (Grashof number) $=d^{3} \rho^{2} g \beta \Delta T / \mu^{2}, N_{S h}$ 
(Sherwood number) $=\mathrm{h}_{\mathrm{m}} \mathrm{d} / \mathrm{D}_{\mathrm{m}}, \quad \mathrm{N}_{\mathrm{Sc}} \quad$ (Schmidt number $)=\mu / \mathrm{d} \rho, \quad \mathrm{ks}$ $=$ Thermal conductivity of the sample, $\mathrm{d}=$ Mean diameter of the particle size of sample, $\mathrm{D}_{\mathrm{m}}=$ Diffusion coefficient (Mass diffusivity)

\section{Sensory evaluation based on selection and training of pane lists}

Sensory tests [32] were adopted with little modification using the 20 trained panelists. At each evaluation section, each panelist received simultaneously samples of fried potato slices labeled with three-digit codes (derived from a standard random table). Panelists were requested to assess each coded sample, and record the degree of difference using a 9-point Hedonic scale. On this scale, 1 represented dislike extremely and 9 represented like extremely.

\section{Statistical analysis}

All data obtained were subjected to analysis of variance (ANOVA) using the general linear models (GLM) procedure of Statistical Analysis System Institute [33]. Means were separated using Duncan's multiple Range Test (DMRT) at 5\% level of probability [34].
$17.18-26.20 \%$ and $13.63-21.61 \%$ respectively. The presence of hydrocolloids in the coating formulation enhance coating pick-up because of their ability to impart viscosity [35]. Coated chips and predried chips had higher coating pick-up, which could be due to wetter surface. This was apparent because wet surfaces are generally needed for solid particles to adhere. Additionally, the binding effect of hydrocolloid is enhanced at higher water activity [36]. High percentage moisture losses result in chips with low oil uptake. The pre-drying treatment could have reduced the superficial moisture on the chips, thereby, leading to more moisture loss and reduced oil uptake, as observed for chips pre-dried before frying [8]. However, hydrocolloid type had no significant effect $(p \leq 0.05)$ on the moisture loss of fried chips, while presence of more hydroxyl group in hydrocolloid molecules could have increased the sites for hydrogen bonding resulting in more affinity for binding water [37]. Oil uptake of the potato chips reflected significant differences $(\mathrm{p} \leq 0.05)$. The reduced oil uptake values may be attributed to combined pre-drying process (high absorption of hydrocolloids by chips) and changes in the structure of hydrocolloids brought about by heat, thereby forming a barrier, where water moves out and oil is absorbed by the chips $[38,39]$.

\section{Results and Discussion}

The coating picks up, moisture loss and oil uptake of sweet potato chips are presented in Table 1 , values ranged from $0.00-7.17 \%$,

\begin{tabular}{|l|l|l|l|}
\hline Sample & Coating pickup (\%) & Moisture Loss & Oil uptake (\%) \\
\hline A & $0.00^{\mathrm{a}}(0.00)$ & $26.20^{\mathrm{c}}(0.40)$ & $17.44^{\mathrm{c}}(0.00)$ \\
\hline B & $0.00^{\mathrm{a}}(0.00)$ & $24.06^{\mathrm{c}}(0.02)$ & $13.63^{\mathrm{a}}(0.02)$ \\
\hline C & $4.08^{\mathrm{b}}(0.00)$ & $17.18^{\mathrm{a}}(0.01)$ & $21.61^{\mathrm{e}}(0.04)$ \\
\hline D & $6.12^{\mathrm{c}}(0.00)$ & $19.78^{\mathrm{b}}(1.48)$ & $15.41^{\mathrm{b}}(0.02)$ \\
\hline E & $7.17^{\mathrm{d}}(0.00)$ & $19.91^{\mathrm{b}}(1.50)$ & $17.82^{\mathrm{d}}(0.00)$ \\
\hline
\end{tabular}

Table 1: Coating pick up, moisture loss and oil uptake of sweet potato chips. Mean value with different superscript within the same column are significantly different at $\mathrm{p} \leq 0.05$. Where $\mathrm{A}=$ Fried potato chips, $\mathrm{B}=$ Pre-dried potato chips before frying, $\mathrm{C}=$ Pre-dried potato coated with egg albumen before frying, $\mathrm{D}=$ Pre-dried potato coated with egg and carboxyl-methylcellulose before frying, $\mathrm{E}=$ Pre-dried potato coated with egg and gum-tragacanth before frying.

Table 2 shows the color profile of sweet potato chips. The lightness $\left(L^{*}\right)$, redness $\left(a^{*}\right)$, yellowness $\left(b^{*}\right)$ and color difference values ranged from 12.00-62.00, 4.00-11.50, 10.00-43.00 and 170.44-176.13, respectively. The optimum values for the color profile were obtained in potato chips pre-dried, coated with egg and gum-tragacanth before frying with significance differences $(\mathrm{p} \leq 0.05)$. A major factor that determines color change in fried food is browning reaction which is often affected by processing temperature, food or ingredient composition and water activity. However, pre-drying influenced the lightness index of the coated chips, led to paler coated fried chips as evidenced by the lower $L^{*}$ value, which could be attributed to maillard's browning reaction [40]. Scientist reported that the ability of gums to bind moisture prevents dehydration and inhibits maillard browning reaction. Pre-drying would normally reduce water activity of potato chips and this could have enhanced non-enzymatic browning. Total color difference is an essential color parameter illustrating the degree of differences resulting from processing measures. The total color difference values estimated for the fried chips were distinctly differed and quite higher as compared with the study [41]. The total color differences were significantly affected by pre-drying and hydrocolloids batter coating of the chips. As suggested by Baik and Mittal [42], processing measures could enhance the maillard reaction and caramelization of sugar resulting in increase in the total color difference values.

\begin{tabular}{|l|l|l|l|l|}
\hline Sample & $\mathbf{L}^{*}$ & $\mathbf{A}^{*}$ & $\mathbf{B}^{*}$ & Color difference $\left(\mathrm{E}^{*}\right)$ \\
\hline A & $27.50^{\mathrm{b}}(4.95)$ & $4.00^{\mathrm{b}}(2.83)$ & $15.00^{\mathrm{a}}(4.24)$ & $172.54^{\mathrm{b}}(0.03)$ \\
\hline B & $60.50^{\mathrm{c}}(4.95)$ & $5.00^{\mathrm{a}}(2.83)$ & $37.00^{\mathrm{b}}(4.24)$ & $175.30^{\mathrm{d}}(0.02)$ \\
\hline
\end{tabular}


Page 5 of 9

\begin{tabular}{|l|l|l|l|l|}
\hline C & $12.00^{\mathrm{a}}(1.41)$ & $4.00^{\mathrm{b}}(2.66)$ & $10.00^{\mathrm{a}}(2.83)$ & $170.44^{\mathrm{a}}(0.04)$ \\
\hline $\mathrm{D}$ & $52.00^{\mathrm{c}}(1.07)$ & $5.00^{\mathrm{b}}(2.83)$ & $25.50^{\mathrm{ab}}(3.44)$ & $173.94^{\mathrm{c}}(0.01)$ \\
\hline $\mathrm{E}$ & $62.00^{\mathrm{c}}(0.00)$ & $11.50^{\mathrm{a}}(0.71)$ & $43.00^{\mathrm{b}}(1.41)$ & $176.13^{\mathrm{e}}(0.03)$ \\
\hline
\end{tabular}

Table 2: Color profile of sweet potato chips. Mean value with different superscript within the same column are significantly different at $\mathrm{p} \leq 0.05$. Where; $\mathrm{L}^{\star}=$ Lightness, $\mathrm{a}^{\star}=$ redness, $\mathrm{b}^{\star}=$ yellowness, $\mathrm{A}=$ =Fried potato chips, $\mathrm{B}=$ Pre-dried potato chips before frying, $\mathrm{C}=$ Pre-dried potato coated with egg albumen before frying, $\mathrm{D}=$ =Pre-dried potato coated with egg and carboxyl-methylcellulose before frying, E=Pre-dried potato coated with egg and gum-tragacanth before frying.

The proximate composition of sweet potato chips as shown in Table 3, moisture, ash, fat, crude fiber, protein and carbohydrate contents ranged from $18.72-37.98 \%, 1.08-1.64 \%, 32.20-48.72 \%, 5.40-14.77 \%$, $0.18-0.79 \%$ and $7.05-28.93 \%$ respectively. The percentage moisture content of the chips was significantly different $(\mathrm{p} \leq 0.05)$. Percentage moisture is one of the significant factors that determine food shelf stability. Only fried potato chips had the least moisture content indicating long keeping period in comparison to other chips.

\begin{tabular}{|l|l|l|l|l|l|l|}
\hline Sample & Moisture (\%) & Ash (\%) & Fat (\%) & Fiber (\%) & Protein (\%) & Carbohydrate (\%) \\
\hline A & $18.72^{\mathrm{a}}(0.02)$ & $1.64^{\mathrm{d}}(0.02)$ & $48.72^{\mathrm{e}}(0.02)$ & $14.77^{\mathrm{d}}(0.06)$ & $0.18^{\mathrm{a}}(0.00)$ & $15.95^{\mathrm{d}}(0.002)$ \\
\hline B & $37.98^{\mathrm{e}}(0.02)$ & $1.32^{\mathrm{b}}(0.02)$ & $43.96^{\mathrm{b}}(0.02)$ & $9.34^{\mathrm{c}}(0.02)$ & $0.35^{\mathrm{b}}(0.00)$ & $7.05^{\mathrm{a}}(0.02)$ \\
\hline C & $36.27^{\mathrm{d}}(0.02)$ & $1.11^{\mathrm{a}}(0.02)$ & $44.96^{\mathrm{c}}(0.02)$ & $5.40^{\mathrm{a}}(0.02)$ & $0.44^{\mathrm{c}}(0.00)$ & $11.82^{\mathrm{b}}(0.00)$ \\
\hline D & $34.72^{\mathrm{c}}(0.02)$ & $1.08^{\mathrm{a}}(0.02)$ & $45.38^{\mathrm{a}}(0.02)$ & $5.40^{\mathrm{a}}(0.02)$ & $0.53^{\mathrm{d}}(0.00)$ & $12.90^{\mathrm{c}}(0.00)$ \\
\hline E & $28.44^{\mathrm{b}}(0.02)$ & $1.48^{\mathrm{c}}(0.02)$ & $32.20^{\mathrm{a}}(0.02)$ & $8.160^{\mathrm{b}}(0.02)$ & $0.79^{\mathrm{e}}(0.00)$ & $28.93^{\mathrm{e}}(0.00)$ \\
\hline
\end{tabular}

Table 3: Proximate composition of sweet potato chips. Mean value with different superscript within the same column are significantly different at $\mathrm{p} \leq 0.05$. Where; $\mathrm{A}=$ Fried potato chips, $\mathrm{B}=$ Pre-dried potato chips before frying, $\mathrm{C}=$ Pre-dried potato coated with egg albumen before frying, $\mathrm{D}=$ Pre-dried potato coated with egg and carboxyl-methylcellulose before frying, E=Pre-dried potato coated with egg and gum-tragacanth before frying.

The ash content is a measure of the mineral contents of food. The ash content of fried potato chips was observed high while pre-dried potato coated with egg albumen before frying gave the least value with significance differences $(\mathrm{p}<0.05)$. The ash content of the chips was generally low compared to the reported values obtained for sweet potato French fries [43]. The pre-drying process of the chips before frying might have affected the mineral content. The sweet potato chips were generally low in protein contents. It is desirable that plant food should be consumed along with animal foods to enhance the nutritive value and reduce the malnutrition of the vulnerable group. Only fried potato chips had the highest fat content and pre-dried fried potato chips coated with egg albumin and gum-tragacanth gave the lowest. This was in agreement with the work [38] who reported that edible coating film reduced oil for coated potato strip. Also reported that using many edible coating films reduced fat absorption and improved moisture retention in starchy products and poultry products [44]. The crude fiber content of potato chips was higher with significance differences $(p \leq 0.05)$ within samples. Un-dried and uncoated fried chips had the highest crude fiber content and the lowest values were observed in the pre-dried potato coated with egg albumen and carboxyl-methylcellulose before frying. Previous study has also revealed that sweet potato is a rich source of soluble fiber [45]. Prerecorded data has indicated that sweet potato root is an energy dense plant [46]. However, the carbohydrate contents of fried chips obtained in this study were low and significantly different in all cases of sample. Pre-dried potato coated with egg and gum-tragacanth before frying, and pre-dried potato chips before frying showed the highest and lowest values, respectively. Lowest trends in values may be due to frying operations, resulting in chemical re-arrangement of the cell structure.

The thermo physical properties of fried and coated potato chips are shown in Table 4. The density, viscosity, thermal conductivity, specific heat capacity and thermal diffusivity values ranged from 333.3-444.0 $\mathrm{kg} / \mathrm{m}^{3}, 0.5281-0.5377$ pas, $22.686-31.403 \mathrm{~W} / \mathrm{m}^{\circ} \mathrm{C}, 198.686-258.383$ $\mathrm{KJ} / \mathrm{kg} \mathrm{K}$ and $2.730 \times 10^{-4}-3.826 \times 10^{-4} \mathrm{~m}^{2} / \mathrm{s}$ respectively. The density of all the samples was below that of water $\left(1000 \mathrm{~kg} / \mathrm{m}^{3}\right)$ and their respective specific heat capacity increases from the results obtained. It implies that greater amount of energy must be removed during cooling or added in the process of heating per $\mathrm{kg}$ mass of the food stuff, whereas the reverse would be the case with lower. When specific heat of a food sample is high, the rate of energy conduction across or within the food material is faster $[25,29,47]$. During frying of the potato chips more heat energy was needed in the frying medium in which there was a relationship between the fried product and the oil. The thermal diffusivity values obtained are less than one and this correlate with thermal diffusivity which was published for some other foods as reported by some researchers $[19,25,29,47,48]$. Thermal diffusivity is a measure of how fast heat propagates or diffuses through a substance. However, the rate at which the potato chips fried depends directly on how heat diffuses into the sample. The thermal conductivity depends on the property of a material to conduct heat. Heat transfer occurs at a lower rate across materials of low thermal conductivity. The pre-dried fried potato coated with egg albumin gave the highest thermal conductivity which implies that heat transfer at a higher rate across the food sample. Since air is a poor conductor of heat, the quantity presents, the better the conduction. In addition to this, higher the 
Page 6 of 9

density greater is the contact between particles, hence higher thermal conductivity. Scientists [50] also reported the same trend for defatted soy flour and hydrated cowpea, respectively.

\begin{tabular}{|l|l|l|l|l|l|}
\hline Sample & Density $\left(\mathbf{g} / \mathbf{m}^{3}\right)$ & Viscosity $(\mathbf{p a s})$ & Ks $(\mathbf{W} / \mathbf{m o C})$ & $\mathbf{C p}(\mathbf{k J} / \mathbf{k g K})$ & $\boldsymbol{\alpha}\left(\mathbf{m}^{2} / \mathbf{s}\right)$ \\
\hline A & 333.3 & 0.5377 & 22.686 & 198.686 & $3.426 \times 10^{-4}$ \\
\hline B & 348.0 & 0.5335 & 31.056 & 256.259 & $3.826 \times 10^{-4}$ \\
\hline C & 364.0 & 0.5281 & 31.403 & 258.383 & $3.339 \times 10^{-4}$ \\
\hline D & 444.0 & 0.5368 & 30.848 & 254.496 & $2.730 \times 10^{-4}$ \\
\hline E & 381.0 & 0.5296 & 29.197 & 228.443 & $3.355 \times 10^{-4}$ \\
\hline
\end{tabular}

Table 4: Thermo physical properties of fried and coated potato chips. Mean value with different superscript within the same column are significantly different at $\mathrm{p} \leq 0.05$; Ks=thermal conductivity, $\mathrm{Cp}=$ specific heat capacity, $\alpha=$ thermal diffusivity where; $\mathrm{A}=$ Fried potato chips, $\mathrm{B}=$ Predried potato chips before frying, $\mathrm{C}=$ Pre-dried potato coated with egg albumen before frying, $\mathrm{D}=$ Pre-dried potato coated with egg and carboxyl methylcellulose before frying, E=Pre-dried potato coated with egg and gum-tragacanth before frying.

The dimensionless numbers obtained for the fried and coated potato chips samples were presented in Table 5. The experimental data of density, specific heat capacity, thermal conductivity, thermal and moisture diffusivity estimated were combined for computation of dimensionless numbers. The Grashof $\left(\mathrm{N}_{\mathrm{Gr}}\right)$ number ranged between 0.024- 0.028. The Prandtl number and Schmidt number $\left(\mathrm{N}_{\mathrm{sc}}\right)$ ranged between $4.14-4.71,2.053 \times 10^{-5}$ and $2.739 \times 10^{-5}$ while the Nusselt $\left(\mathrm{N}_{\mathrm{Nu}}\right)$ and Sheerwood $\left(\mathrm{N}_{\mathrm{Sh}}\right)$ number ranged between $0.0167-0.0209$ and $9.69 \times 10^{-8}$ and $1.01 \times 10^{-7}$, respectively. The dimension less numbers such as Grashof $\left(\mathrm{N}_{\mathrm{Gr}}\right)$, Prandtl $\left(\mathrm{N}_{\mathrm{Pr}}\right)$, Schmidt $\left(\mathrm{N}_{\mathrm{sc}}\right)$, Nusselt $\left(\mathrm{N}_{\mathrm{Nu}}\right)$ and Sherwood $\left(\mathrm{N}_{\mathrm{Sh}}\right)$ numbers were determined from the estimated thermo-physical data. The Grashof number increases with increase in the treatment given to the sample but decreases with coating of the potato with egg albumin and carboxy methylcellulose (CMC). The Grashof number plays the same role that Reynolds number played in forced convection and the values represent the flow regime in natural convection only. The prandtl number decreases respectively. Only fried potato chips had the highest prandtl number. The prandtl number is seen to be a ratio reflecting the ratio of the rate that viscous forces penetrate the fried chips to the rate that thermal energy penetrates. As a consequence, the prandtl number is proportional to the rate of growth of the two boundary layers [47]. The schmidt number also decreases respectively. The prandtl number obtained was used to compare momentum and heat transfer by diffusion while Schmidt number was used to compare momentum and mass transfer by diffusion [31].

\begin{tabular}{|l|l|l|l|l|l|}
\hline Sample & $\mathbf{N}_{\mathrm{gr}}$ & $\mathbf{N}_{\mathrm{pr}}$ & $\mathbf{N}_{\mathrm{sc}}$ & $\mathbf{N}_{\mathrm{nu}}$ & $\mathbf{N}_{\mathrm{Sh}}$ \\
\hline A & 0.024 & 4.71 & $2.739 \times 10^{-5}$ & 0.0167 & $9.70 \times 10^{-8}$ \\
\hline B & 0.026 & 4.40 & $2.603 \times 10^{-5}$ & 0.0168 & $9.98 \times 10^{-9}$ \\
\hline C & 0.028 & 4.35 & $2.463 \times 10^{-5}$ & 0.0180 & $1.02 \times 10^{-7}$ \\
\hline D & 0.032 & 4.43 & $2.053 \times 10^{-5}$ & 0.0209 & $9.69 \times 10^{-8}$ \\
\hline E & 0.029 & 4.14 & $2.360 \times 10^{-5}$ & 0.0177 & $1.01 \times 10^{-7}$ \\
\hline
\end{tabular}

Table 5: Dimensionless numbers of fried and coated potato chips. NGr-Grashof number, NPr-Prandtl number, NSc-Schmidt number, NNu Nusselt number, NSh-Sherwood number. where; A=Fried potato chips, B=Pre-dried potato chips before frying, C=Pre-dried potato coated with egg albumen before frying, $\mathrm{D}=$ Pre-dried potato coated with egg and carboxyl-methylcellulose before frying, E=Pre-dried potato coated with egg and gum-tragacanth before frying.

The Nusselt and Sherwood numbers obtained represent the enhancement of heat and mass transfer, respectively through a fluid layer as a result of convection relative to conduction across the same fluid layer [47]. The Nusselt number is view as the ratio of the conduction resistance of the fried product. The higher the Nusselt and Sherwood number the more effective the convective heat and mass transfer, respectively. Consequently, the values of both Nusselt and Sherwood numbers were used for the estimation of convective heat and mass transfer coefficient. The estimated heat and mass transfer coefficient of the fried and coated potato chips samples are presented in Table 6 . The heat transfer coefficient during frying was affected by bubble flow direction, velocity, bubble frequency, and then magnitude of oil agitation. Bubbles that formed at the top surface escaped upward immediately, providing greater oil agitation. Bubbles leaving the lateral surface promoting a different type of agitation. The heat transfer coefficient of the fried chips sample under natural convection ranged between $25.26-42.98 \mathrm{~W} / \mathrm{m}^{2}{ }^{\circ} \mathrm{C}$, while the mass transfer coefficient ranged between $3.80 \times 10^{-12}$ and $4.01 \times 10^{-12} \mathrm{~m} / \mathrm{s}$. The values obtained are similar with the published values for natural convective heat and mass transfer coefficient in some food process operations as published $[51,52]$. These values were found useful in determining the total heat and mass transfer rates during frying process and are important 
considerations for mass production of fried potato chips in an industrial scale.

\begin{tabular}{|l|l|l|}
\hline Sample & Heat transfer Coefficient $\left(\mathbf{W} / \mathbf{m}^{2}{ }^{\circ} \mathbf{C}\right)$ & Mass transfer coefficient $(\mathbf{m} / \mathbf{s})$ \\
\hline A & 25.26 & $3.81 \times 10^{-12}$ \\
\hline B & 34.78 & $3.92 \times 10^{-12}$ \\
\hline C & 37.68 & $4.01 \times 10^{-12}$ \\
\hline D & 42.98 & $3.80 \times 10^{-12}$ \\
\hline E & 34.45 & $3.97 \times 10^{-12}$ \\
\hline
\end{tabular}

Table 6: Heat and mass transfer coefficient of fried and coated potato chips. Where; $A=$ Fried potato chips, $B=$ Pre-dried potato chips before frying, $\mathrm{C}=$ Pre-dried potato coated with egg albumen before frying, $\mathrm{D}=$ Pre-dried potato coated with egg an cellulosecarboxyl-methylcellulose before frying, $\mathrm{E}=$ Pre-dried potato coated with egg and gum-tragacanth before frying.

The sensory properties of fried potato chips are presented in Table 7. Development of desirable sensorial properties in fried products is attributed to high heat transfer rates [53]. The sensory properties of fried potato chips indicated slight significance differences $(p \leq 0.05)$. The color of the potato fried chips ranged from 6.80-8.20. Color is one of the most important physical attributed that greatly influences consumer perception and can summarily lead to rejection of a product. Few observed that during frying, the color of the product is developed as a result of Maillard [54] and is influenced by factors such as reducing sugar and amino acid content. The highest color value was observed in the pre-dried potato fried chips coated with egg albumen and carboxyl-methylcellulose, while the lowest value was obtained by the chips pre-dried, coated with egg and gum tragacanth before frying. The taste scores ranged from $6.80-8.10$. The potato chips pre-dried, coated with egg albumen and carboxyl-methylcellulose gave the highest value while the least was observed in the only pre-dried chips before frying. The hydrocolloids used in coating the potato chips had significant effect on the potato chips taste. The texture of the potato chips ranged from 6.50-7.70. The best texture was observed in chips pre-dried, coated with egg albumen and carboxyl-methylcellulose, while the least value was obtained by chips pre-dried, coated with egg albumen and gum tragacanth.

\begin{tabular}{|l|l|l|l|l|l|}
\hline Sample & Color & Taste & Texture & Aroma & $\begin{array}{l}\text { Overall } \\
\text { Acceptabilit } \\
\mathbf{y}\end{array}$ \\
\hline A & $7.80^{\mathrm{ab}}$ & $7.50^{\mathrm{ab}}$ & $7.20^{\mathrm{ab}}$ & $7.40^{\mathrm{ab}}$ & $8.00^{\mathrm{ab}}$ \\
\hline B & $8.20^{\mathrm{b}}$ & $7.20^{\mathrm{ab}}$ & $7.30^{\mathrm{ab}}$ & $8.10^{\mathrm{a}}$ & $7.20^{\mathrm{ab}}$ \\
\hline C & $7.60^{\mathrm{ab}}$ & $7.80^{\mathrm{ab}}$ & $7.50^{\mathrm{ab}}$ & $7.30^{\mathrm{a}}$ & $6.60^{\mathrm{ab}}$ \\
\hline D & $8.20^{\mathrm{b}}$ & $8.10^{\mathrm{b}}$ & $7.70^{\mathrm{b}}$ & $7.40^{\mathrm{a}}$ & $8.10^{\mathrm{b}}$ \\
\hline E & $6.80^{\mathrm{a}}$ & $6.80^{\mathrm{a}}$ & $6.50^{\mathrm{a}}$ & $6.50^{\mathrm{a}}$ & $6.20^{\mathrm{a}}$ \\
\hline
\end{tabular}

Table 7: Sensory properties of potato chips. Mean value with different superscript within the same column are significantly different at $\mathrm{p} \leq$ 0.05 . Where; $A=$ Fried potato chips, $B=$ Pre-dried potato chips before frying, $\mathrm{C}=$ Pre-dried potato coated with egg albumen before frying, $\mathrm{D}=$ Pre-dried potato coated with egg and carboxyl-methylcellulose before frying, $\mathrm{E}=$ Pre-dried potato coated with egg and gum-tragacanth before frying.
Texture of chips is a vital criterion that determines the consumer acceptance [55]. The result of this study showed that the texture of potato chips processed by frying directly, pre-dried and fried, and predried, coated with egg albumen and fried were not significantly $(\mathrm{p} \leq$ $0.05)$ different. The aroma of the fried potato chip ranged from 6.50-8.10. The potato chips with the best aroma was observed from the pre-dried chips before frying, while the chips pre-dried, coated with egg albumen and gum tragacanth recorded the lowest value. The overall acceptability of the potato chips ranged from $6.20-8.10$. The pane list preferred the potato chips which were processed by predrying, coated with egg albumen and carboxyl-methylcellulose while the least preferred was observed in the chips processed by pre-drying, coated with egg albumen and gum tragacanth. The chip which was coated with the different type of hydrocolloids were significantly ( $\mathrm{p} \leq$ 0.05 ) different. These results showed that the type of hydrocolloid applied in the production of potato chips had significant effect on the sensory properties of the potato chips.

\section{Conclusion}

The study revealed that desirable quality attribute depends on choice of processing and food material use. As observed, potato chips pre-dried, coated with egg albumin and gum-tragacanth gave desirable coating pick up, moisture loss, oil uptake, color profile and proximate composition. Nevertheless, the mean sensory score indicated that predried potato coated with egg and carboxyl-methylcellulose before frying was the most preferred. Future studies on descriptive sensory test and keeping quality of the chips are therefore recommended. Furthermore, great reduction in the fat content of the chips will decline tendency of obesity and equally reduce cholesterol level. Thermo physical properties, dimensionless numbers and heat and mass transfer data obtained were important parameters indicating the extent of convective effects and correlation between diffusion barrier of heat and mass transfer and are essential considerations for mass production of fried potato chips.

\section{Acknowledgements}

Funding provided by the Nigerian government through the Tertiary Education Trust Fund (TETFUND) of the Federal Ministry of Education, is duly acknowledged. 


\section{References}

1. Bhattiprolu S (2004) Color, Texture and Rehydration Characteristics of Ohmically treated Sweet Potatoes. A Thesis submitted to the Graduate Faculty of the Louisiana State University and Agricultural and Mechanical College, Louisiana, USA.

2. USDA (U.S. Department of Agriculture), Agricultural Research Service (2009) USDA National nutrient Database for standard reference. Release 22. Nutrient Data Laboratory.

3. Okorie SU, Onyeneke EN (2012) Production and Quality Evaluation of Baked Cake From Blend of Sweet Potatoes and Wheat Flour. J Nutri Appl Sci 3: 52-55.

4. Farkas BE, Singh RP, Rumsey TR (1996) Modeling Heat and Mass Transfer in Immersion Frying. J Food Engg 29: 211-226.

5. Vitrac O, Dufour D, Trystram G, Raoult Wack AL (2002) Characterization of Heat and Mass Transfer during Deep-fat Frying and Its Effect on Cassava Chip Quality. J Food Engg 53: 161-176.

6. Krokida MK, Oreopoulou V, Maroulis ZB, Marinos-Kouris D (2001) Deep Fat Frying of Potato Strips-Quality Issues. Dry Technol 19: 879-935.

7. Pedreschi F, Moyano P (2005) Effect of Pre-Drying on Texture and Oil Uptake of Potato Chips. Leben Wiss Technol 38: 599-604.

8. Alimi BA, Shittu TA, Sanni LO, Arowolo TA (2013) Effect of Pre-drying and Hydrocolloid Type on Colour and Textural Properties of Coated Fried Yam Chips. J Food Technol 31: 97-102.

9. Dogan SF, Sahin S, Suminu G (2005) Effects of Batters Containing Different Protein Types on the Quality of Deep Fat Fried Chicken Nuggets. Eur Food Res Technol 220: 502-508.

10. Akdeniz N, Sahin A, Sumnu G (2006) Functionality of Batters Containing Different Gums for Deep Fat Frying of Carrot Slices. J Food Engg 75: 522-526.

11. Suderman DR (1983) Use of Batter and Breeding's on Food Products. A review. In: Suderman DR, Cunningham FE (eds.), Batter and Breeding Technology. AVI Publishing Company, Inc., Westport, CT, USA.

12. Parinyasiri T, Chen TC, Reed RJ (1991) Yields and Breading Dispersion of Chicken Nuggets during Deep-Fat Frying as Affected by Protein Content of Breading Flour. J Food Process Preserv 15: 367-374.

13. Maskat MY, Yip HH, Mahali HM (2005) The Performance of a Methy Cellulose-treated Coating during the Frying of a Poultry Product. Internat J Food Sci Technol 40: 811-816.

14. Primo-Martin C, Sanz T, Steringa DW, Salvador A, Fiszman SM, et al. (2010) Performance of Cellulose Derivatives in Deep-Fried Battered Snacks: Oil Barrier and Cripsy Properties. Food Hydrocolloid 24: 702-708.

15. Aminlari M, Ramezhani R, Khalili MH (2005) Production of Protein Coated Low Fat Potato Chips. Food Sci Technol Internat 11: 177.

16. AOAC (1995) Official Methods of Analysis of Association of official analytical chemist. 16th edn. Washington, VA, USA.

17. Yam KL, Papadakis SE (2004) A Simple Digital Imaging Method for Measuring and Analyzing Color of Food Surfaces. J Food Engg 61: 137-142.

18. AOAC (2000) Official Methods of Analysis. Maryland: Association of Official Analytical Chemists International.

19. Nwanekezi EC, Ukagu JC (1999) Determination of engineering properties of some Nigerian fruits and vegetables. Nigerian Food Journal 17: 55-59.

20. Mohsenin NN (1980) Thermal Properties of Food and Agricultural Materials. Gordon and Breach Science Publisher, New York, United States, pp: 65-98.

21. Proud LM, Lund DB (1983) Thermal Properties of Beef Loaf Produced in Food Service Systems. J Food Sci 48: 677-680.

22. Tong CH, Sheen S, Shah KK, Huang VT, Lund DB (1993) Reference Materials for Calibrating Probes Used for Measuring Thermal Conductivity of Frozen Foods. J Food Sci 58: 186-192.

23. Carslaw HS, Jaegar JC (1959) Conduction of Heat in Solids. 2nd edn. Oxford University Press, London, pp: 190-196.
24. Incropera FP, DeWitt DP (1996) Fundamentals of Heat and Mass Transfer. 4th edn. John Wiley and Sons, New York, United States.

25. Rapusas RS, Driscoll RH (1995) Thermophysical properties of Fresh and Dried White Onion Slices. J Food Engg 24: 149-164.

26. Crank J (1975) The Mathematics of Diffusion. Oxford University Press, Ely House, London.

27. AOAC (1990) Official Methods of Analytical Chemist. 15th edn. AOAC Arlington, Viriginia, Unites States.

28. Wetly JR, Wicks CE, Rorrer G, Wilson RE (1993) Fundamentals of Momentum, Heat and Mass Transfer. John Wiley and Sons, Mexico, Limusa, USA, pp: 20-30.

29. Singh RP, Heldman DR (1993) Introduction to Food Engineering. Academic Press Inc. London, pp: 30-125.

30. Jaczynski J, Park JW (2002) Temperature Prediction during Thermal Processing of Surimi Seafood. J Food Sci 67: 3053-3057.

31. Holman JP (1997) Heat Transfer. McGraw Hill International Book Company. 8th edn, London, pp: 223-292.

32. Obatolu VA, Skonberg DI, Camire ME, Dougherty MP (2005) Effect of Moisture Content and Screw Speed on the Physical and Chemical Properties of an Extruded Crab-Based Snack. Food Sci Technol Internat 11: $121-127$.

33. SAS (2003) SAS 9.1 Qualification tools user guide. SAS Institute Incorporation, Cary, N.C., USA.

34. Steel RGD, Torrie JH (1980) Principle and Procedures of Statistics. 2nd edn. McGraw Hill Book Company, New York.

35. Hsia HY, Smith DM, Steffe JF (1992) Rheological properties and adhesion characteristics of flour based batters for chicken nuggets as affected by three hydrocolloids. J Food Sci 571: 16-18, 24.

36. Patil JS, Singhal RS, Kulkarni PR (2001) Screening of Different Hydrocolloids for Improving the Quality of Fried Papad. Eur J Lip Sci Technol 103: 722-728.

37. Aguirre-Cruz A, Mendez-Montealvo G, Solorza-Feria J, Bello-Perez LA (2005) Effect of Carboxymethylcellulose and Xanthan Gum on the Thermal, Functional and Rheological Properties of Dried Nixtamalised Maize Masa. J Carbo Pol 62: 222-231.

38. Rimac-Brncic S, Lelas V, Rade D, Simundic B (2004) Decreasing of Oil Absorption in Potato Strips during Deep Fat Frying. J Food Engg 64: 237-241.

39. Abu-Alruz K (2013) Effect of Pre Drying and Using Hydrocolloid System on Frying Characteristics of Fried Potato. Amer J Agri Biol Sci 8: 282-286.

40. Ibarz A, Pagan J, Garza S (1999) Kinetic Models for Colour Changes in Pea Puree during Heating at Relatively High Temperature. Journal of Food Engineering 39: 415-422.

41. Adeyanju JA, Olajide JO, Adedeji AA (2016) Optimization of Deep-Fat Frying of Plantain Chips (Ipekere) Using Response Surface Methodology. J Food Process Technol 7: 584.

42. Baik OD, Mittal GS (2003) Kinetics of Tofu Color Changes during DeepFat Frying. LWT- Food Sci Technol 36: 43-48.

43. Sosinski B, He J, Flores CR, Pokrzywa M, Bruckner A, et al. (2001) Sweet Potato Genomics at North Carolina State University. In: Ames T (ed). Proceedings of the First International Conference on Sweet Potato. Food and Health for the future. Acta Horticulture 583: 69-76.

44. Holownia KI, Chinnan MS, Erickson MC, Mallikarjunan P (2000) Quality Evaluation of Edible Film-Coated Chicken Strips and Frying Oils. J Food Sci 65: 1087-1090.

45. Woolfe JA (1992) Sweet Potato: An Untapped Food Resource (In Press). Cambridge, U.K.

46. FAO (1989) The state of food and agriculture. Food and Agriculture Organisation of the United Nations, Rome, Italy.

47. Sobowale SS, Awonorin SO, Shittu TA, Ajisegiri ESA, Adebo OA, et al. (2017)Modeling of the Garification Process of Fermented Cassava Mash. J Bioprocess Biotechniques 7: 311 .

48. Wallapapan K, Sweat VE, Arce JA, Dahm PF (1984) Thermal Diffusivity and Conductivity of Defatted Soy Flour. Transaction Amer Soc Agri Engg 27: 1613 . 
Citation: Sobowale SS, Omotoso BO (2018) Effect of Pre-Drying and Hydrocolloids Batter Coating during Heat and Moisture Transfer of Coated Fried Potato Chips. J Bioprocess Biotech 8: 328. doi:10.4172/2155-9821.1000328

Page 9 of 9

49. Wallapapan K, Sweat VE (1982) Thermal Conductivity of Defatted Soyflour. Transactions of the American Society of Agricultural Engineers 27: 1610-1613.

50. Taiwo KA, Akanbi CT, Ajibola OO (1996) Thermal Properties of Ground and Hydrated Cowpea. J Food Engg 29: 249-256.

51. Baik OD, Mittal GS (2002) Heat Transfer Coefficient during Deep Fat Frying of A Tofu Disc. Ameri Soc Agri Eng 45: 1493-1499.

52. Sobowale SS, Awonorin SO, Shittu TA, Ajisegiri ESA (2014) Artificial Neural Network (ANN) of Simultaneous Heat and Mass Transfer Mode during Reconstitution of Gari Granules into Thick Paste. Int J Chem Engg App 5: 462-467.
53. Hubbard LJ, Farkas BE (2000) Influence of Oil Temperature on Heat Transfer during Immersion Frying. Food Process J Preserv 24: 143-162.

54. Miranda ML, Aguilera JM (2006) Structure and Texture Properties of Fried Potato Products. Food Rev Inter 22: 173-201.

55. Setiady D, Tang J, Younce F, Swanson BA, Rasco BA, et al. (2009) Porosity, Color, Texture and Microscopic Structure of Russet Potatoes Dried Using Microwave Vacuum, Heated Air, And Freeze Drying. ASABE Applied Engineering in Agriculture 25: 719-724. 